PART 3

Material Culture and Culture 
Blair Fowlkes-Childs - 9789004326750 Downloaded from Brill.come4/26/2023 11:17:13AM via free access 


\title{
Palmyrenes in Transtiberim: Integration in Rome and Links to the Eastern Frontier ${ }^{1}$
}

\author{
Blair Fowlkes-Childs
}

The subject of Palmyrenes' integration as residents of Rome involves a topic crucial to this workshop, namely, how people from the worlds at the edge of the Empire established new lives when they settled in the capital. Palmyrene expatriates built a temple in Rome's Transtiberim neighborhood where they venerated their civic gods, including Bel, Malakbel, Aglibol, Iarhibol, Astarte and Ares Patroios, most likely during the first third of the second century AD, a period approximately contemporaneous with the construction of the temple of Bel and other Palmyrene gods in Palmyra. ${ }^{2}$ The religious dedications extant in Rome (despite their limited number and often fragmentary condition) attest to the Palmyrenes' strong ties to their city of origin, and in general do not provide much evidence for assimilation in Rome. The remarkable traditionalism of most of the dedications with respect to choices of language, iconography and medium indicates that the dedicators maintained their identities as Palmyrenes (often including their original names and lineage), and were rooted in their own culturally specific religious practices. An elaborate altar dedicated to Sol, Malakbel and other Palmyrene gods, however, stands out, and a new study of its iconography and inscriptions that also considers local religious topography enhances our understanding of Palmyrenes' integration in Rome substantially (Figs. 10.4a-10.4d). The altar's remarkable images and its inscriptions attest to a connection between worshippers of the Roman god Sol and Palmyrenes who venerated Malakbel that is particularly striking because a

1 This article is a modified version of the paper I presented at the 11th workshop of IMEM in New York in June 2013. I would like to thank Michael Peachin and Daniëlle Slootjes, the conference organizers and editors of this volume, for all of their assistance. I also thank Amanda Claridge for an informative discussion of marble workshops in Rome.

2 The only object in the Palmyrene corpus in Rome securely linked to a building, perhaps an aedicula, is a fragment of a central piece of a marble entablature with a Greek inscription, dated probably to the reign of Antoninus Pius. IGUR 123; IG XIV, 1035; IGRR I, 47. Rome, Museo Nazionale Romano 40564. $12.5 \times 24 \times 3.5 \mathrm{~cm}$. See also CIS II, 3, 3902 and François Chausson,"Vel Iovi vel Soli: quatre études autour de la Vigna Barberini (191-354)," Mélanges de l'École française de Rome 107 (1995), 671, H. 
porticus for Sol was located in the same neighborhood as the Palmyrene temple (possibly in close proximity). This glimpse of religious life at a local level in Transtiberim indicates that some Palmyrenes were more integrated than most of their dedications suggest, and raises the subject of whether or not some members of the Palmyrene community also participated in religious activities elsewhere in Rome, without leaving discernable records. Lucinda Dirven's observation about foreigners at Dura-Europos applies equally to Palmyrenes in Rome: "strangers who retain markers of their foreignness dominate the picture, whereas they may not be representative necessarily of all the people of a particular region." ${ }^{3} \mathrm{~A}$ reappraisal of the whole Rome corpus is well worthwhile given the recent research on religion in Palmyra and amongst Palmyrene residents of Dura-Europos, on bilingual inscriptions in the Roman world, and on the religious topography of Transtiberim during the imperial period. Above all, an interdisciplinary approach to the material that synthesizes evidence from epigraphy, iconography and topography is essential.

1

\section{Language Choices in the Dedications to Palmyrene Gods Discovered in Rome}

The significance of Palmyrenes' language choices in their dedicatory inscriptions requires evaluation in conjunction with a study of the iconography and medium of each dedication, both in the context of Rome and in comparison with conventions at Palmyra. A few initial observations about language choices may help to frame the discussion overall. Greek and Palmyrene Aramaic dominate the corpus, whereas Latin is rare. The choice to inscribe at Rome in Greek can be interpreted, as J.N. Adams suggests, as a less forceful sign of Palmyrene identity than the decision to use Palmyrene Aramaic: "the dedicators were able to pay lip service to their origins without presenting themselves as out and out aliens, given that the Romans too were devotees of Greek culture and that the city abounded in Greek inscriptions of one sort or another."4 Greek was, of course, readable by a much higher percentage of the local population than Palmyrene was, and several inscriptions are bilingual Greek/Palmyrene. In addition, when Palmyrene is not used, its exclusion raises the question as to whether the dedicators' language choice can be interpreted as a statement

3 Lucinda Dirven, "Strangers and Sojourners: the Religious Behavior of Palmyrenes and other Foreigners in Dura-Europos," in Lisa R. Brody and Gail L. Hoffman (eds.), Dura-Europos: Crossroads of Antiquity (Chestnut Hill, MA and Chicago 2011), 203.

4 J.N. Adams, Bilingualism and the Latin Language (Cambridge 2003), 249 and 251. 
of their permanent settlement in Rome and desire to integrate. ${ }^{5}$ The rarity of Latin is striking, and its use in Rome is an obvious reflection of local context, especially in view of the minor role Latin played in inscriptions at Palmyra. In fact, the city's status as the only publicly bilingual Greek/Aramaic city in the region was unique. ${ }^{6}$ Furthermore, Latin may also not have been considered appropriate for certain religious dedications, as Adams points out with regard to the aedicula and silver statuette dedicated to Aglibol and Malakbel at Rome inscribed in Greek and Palmyrene. ${ }^{7}$

The foundation of a temple for Palmyrene gods in Rome is recorded by two bilingual Latin/Greek inscriptions: the choices of Latin and Greek, and the exclusion of Palmyrene, reflect local context. The references to the emperor are written in Latin only, as Adams notes, and therefore precede the Greek inscriptions in both instances. ${ }^{8}$

CIL VI, 50; ILS, 4334; IGUR, 117; IG XIV, 969; IGR I, 43:

Pro salute Imp (eratoris) [Caesaris --------]

C. Licinius $N$ [------ et Heliodorus]

Palmyrenus [aedem Belo ---------]

constitu[erunt -------]

'H

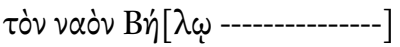

$\Pi \alpha \lambda \mu \nu \rho \eta \nu[\hat{\omega} \alpha \dot{\alpha} \theta \dot{\theta} \eta \alpha \nu$----------]

CIL VI, 51; IGUR I, 118; IG, XIV, 970; IGR, I, 44:

[Pro salute Imp(eratoris) Caesaris -----------]

[C. Licinius $N$------ et Heliodorus Palmyrenus]

[ae]dem Belo stat[uerunt ---]

5 See comments by Eugenia Equini Schneider, "Il santuario di Bel e delle divinità di Palmira. Comunità e tradizioni religiose dei Palmireni a Roma," Dialoghi di Archeologia 5 (1987), 84.

6 Ted Kaizer, The Religious Life of Palmyra: a Study of the Social Patterns of Worship in the Roman Period (Stuttgart 2002), 27.

7 Adams 2003, op. cit. (n. 4), 252.

8 Adams 2003, op. cit. (n. 4), 249. 


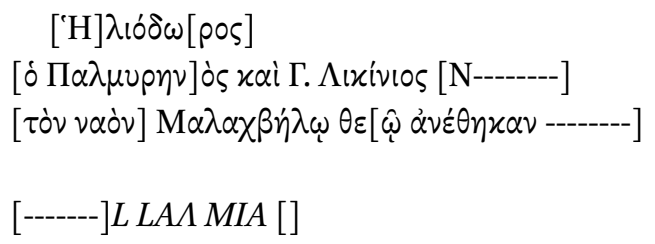

Both the Latin and Greek texts indicate that the gods Bel and Malakbel were distinct, supporting Dirven's argument against their assimilation: "the two gods were worshipped side by side.... thus there is no ground for the assumption that Malakbel replaced Bel. ${ }^{\prime 9} \mathrm{~A}$ temple for Bel is mentioned in $C I L \mathrm{VI}, 5^{1}$

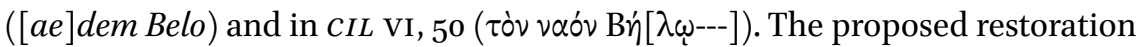

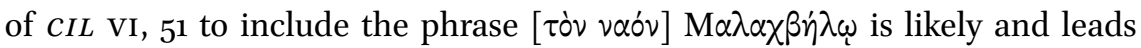
to speculation about whether separate temples for each god existed within the same sanctuary. It should also be noticed that the same benefactors are mentioned in both inscriptions. Although only Heliodorus is identified specifically as a Palmyrene, the gentilicium Licinius is attested four times at Palmyra, and may indicate that the benefactor in Rome belonged to a Palmyrene family, known to have belonged to the priest class, and which had gained Roman citizenship. ${ }^{10}$

Several aspects of the temple of Bel at Palmyra are relevant to a clearer understanding of the Palmyrene temple in Rome, with respect both to the gods worshipped as well as the roles of private benefactors. Ted Kaizer's cautionary assessment must however be kept in mind: "the religion of Palmyrene expatriates cannot simply be explained as copying the religious world of their hometown, and different social and economic conditions are known to have had a strong effect on the choice of deities to whom dedications were made."11 $\mathrm{He}$ establishes that the name "temple of Bel" became typical at Palmyra, but is in fact a "simplification of the actual cultic situation," which included the veneration of numerous Palmyrene gods together: inscriptions dated to both the early first century $\mathrm{AD}$ and to the second half of the second century refer to a "temple of Bel" and to the "house of the gods of the Palmyrenes." In addition to the gods Iarhibol and Aglibol, the goddess Astarte, for example, was worshipped

Lucinda Dirven, The Palmyrenes of Dura-Europos: A Study of Religious Interaction in Roman Syria. Religions in the Graeco-Roman World 138 (Leiden 1999), 173. For a comprehensive recent analysis of the god Bel, see Michał Gawlikowski, "Bel of Palmyra," in Michael Blömer, Achim Lichtenberger and Rubina Raja (eds.), Religious Identity in the Levant from Alexander to Muhammed: Continuity and Change. Contextualising the Sacred (Leuven 2014), 4, 247-254.

$10 \quad$ Equini Schneider 1987, op. cit. (n. 5), 71-72.

11 Kaizer 2002, op. cit. (n. 6), 112. 
alongside Bel at Palmyra, and her cult image very likely housed in the south adyton, newly built in the second half of the first century. ${ }^{12}$ Rather than a major imperial benefaction, as had previously been supposed, Kaizer's study of the epigraphic corpus reveals that individual Palmyrene citizens financed the temple's construction over a prolonged period: ${ }^{13}$ the building of the cella extended into the second century. ${ }^{14}$ In Rome, private benefactors fulfilled comparable roles as temple founders and benefactors, and the two dedicatory inscriptions potentially point to direct interconnections between the Palmyrenes resident in Rome and those back home.

Two inscribed marble relief sculptures reflect Palmyrene conventions with regard to the deities venerated, epigraphic formulas, iconography and their actual format as reliefs; when evaluated in conjunction with recent research on religion at Palmyra, both contribute to an understanding of Palmyrene identity and religious life in Rome despite their fragmentary condition. The relief dedicated to Bel, Iarhibol and probably also Aglibol features a bilingual Palmyrene/ Greek inscription that emphasizes the dedicator Maqqai/Makkaios' lineage, in accordance with the typically Palmyrene focus on ancestry (Fig. 10.1).

IGUR 120; IG XIV, 972; IGRR I, 46; CIS II, 3904; PAT 0249:

English translation of the Palmyrene Aramaic (Adams 2003, 251).

[To Bel, Iarhibol and Aglibol: made (this)

Maqqai son of Male (son of) Lišam] š and

Šo'adu son of Taime (son of) Lišamšai, and

offered (it).

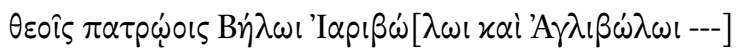

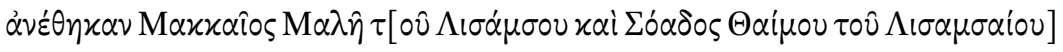

12 Kaizer 2002, op. cit. (n. 6), 70 and 198-200; Ted Kaizer, "Reflections on the Dedication of the Temple of Bel at Palmyra in A.D. 32," in Lukas de Blois, Peter Funke and Johannes Hahn (eds.), The Impact of Imperial Rome on Religions, Ritual and Religious Life in the Roman Empire: Proceedings of the Fifth Workshop of the International Network of Empire (Roman Empire, 200 B.C.-A.D. 476) (Leiden 2006), 96 and 104-105.

13 Kaizer 2002, op. cit. (n. 6), 67-71 (with references) and Kaizer 2006, op. cit. (n. 12), 95.

14 Gawlikowski 2014, op. cit. (n. 9), 248-249; see also Michał Pietryzkowski, Adyta światyń palmyreńskich. Studium funkcji i formy (Warsaw 1997). 


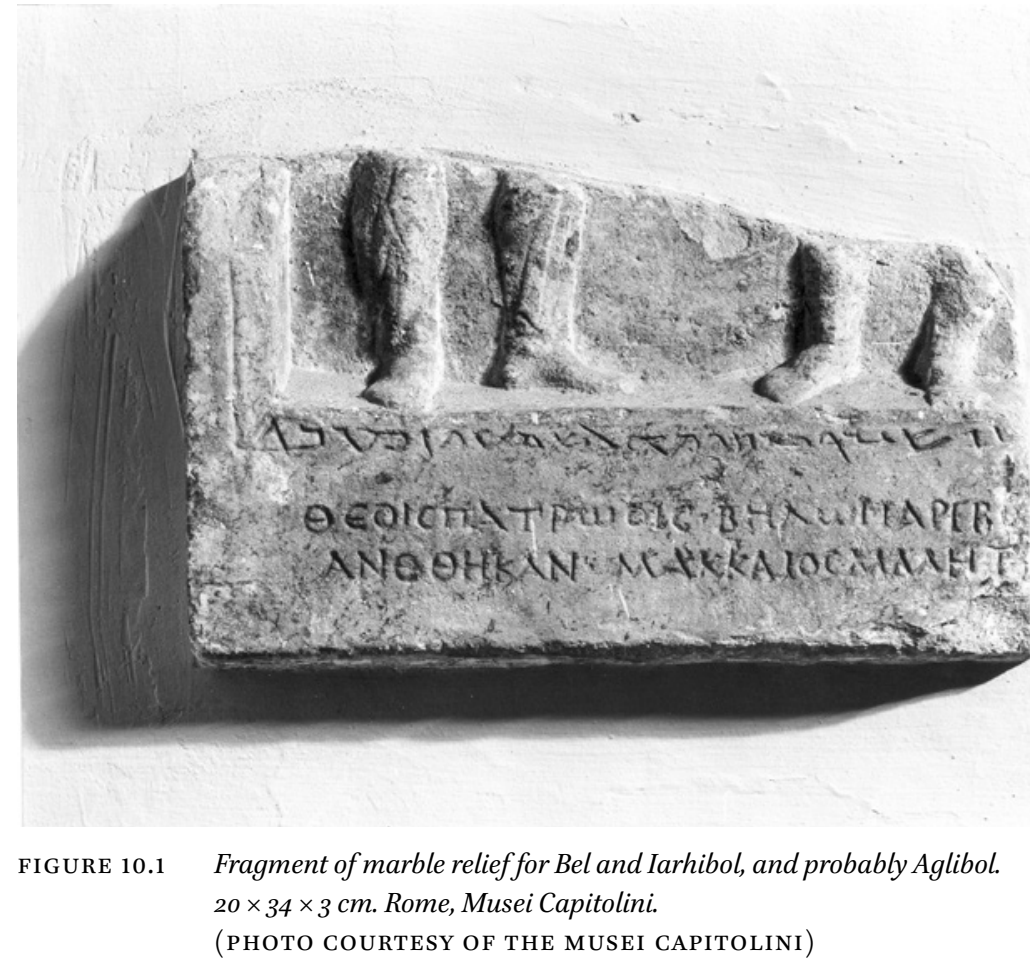

It is possible to reconstruct the relief's original iconography: the boots and the lower sections of the trousers of two figures are extant, enough to indicate that the relief most likely originally depicted the gods Bel and Aglibol dressed in their usual outfits, which included cuirasses and mantles as well as trousers. Bel is typically crowned with a polos and diadem, holding a scepter in his right hand and a sword in his left. He is most likely identifiable with the figure on the right, since he usually appears in the center of a divine trio, with Iarhibol on his right and Aglibol on his left, leading to the identification of the second figure as Aglibol. Such close adherence to conventional Palmyrene representations of divinities suggests strong ties between the dedicators in Rome and their home city.

The marble relief fragment that depicts the head of the goddess Astarte wearing a kalathos and a veil, with her name inscribed in Greek in the frame, is another example of traditionalism with respect to language and iconography in the corpus, as well as of ties to Palmyra (Fig. 10.2).15

15 Carlo Ludovico Visconti, "Escavazioni della Vigna Bonelli fuori della Porta Portese negli anni 1859 e 6o," Annali dell'Istituto di corrispondenza archeologica 32 (1860), 423-424, thought that the Astarte figure belonged to the same relief as the Bel, Iarhibol and Aglibol 


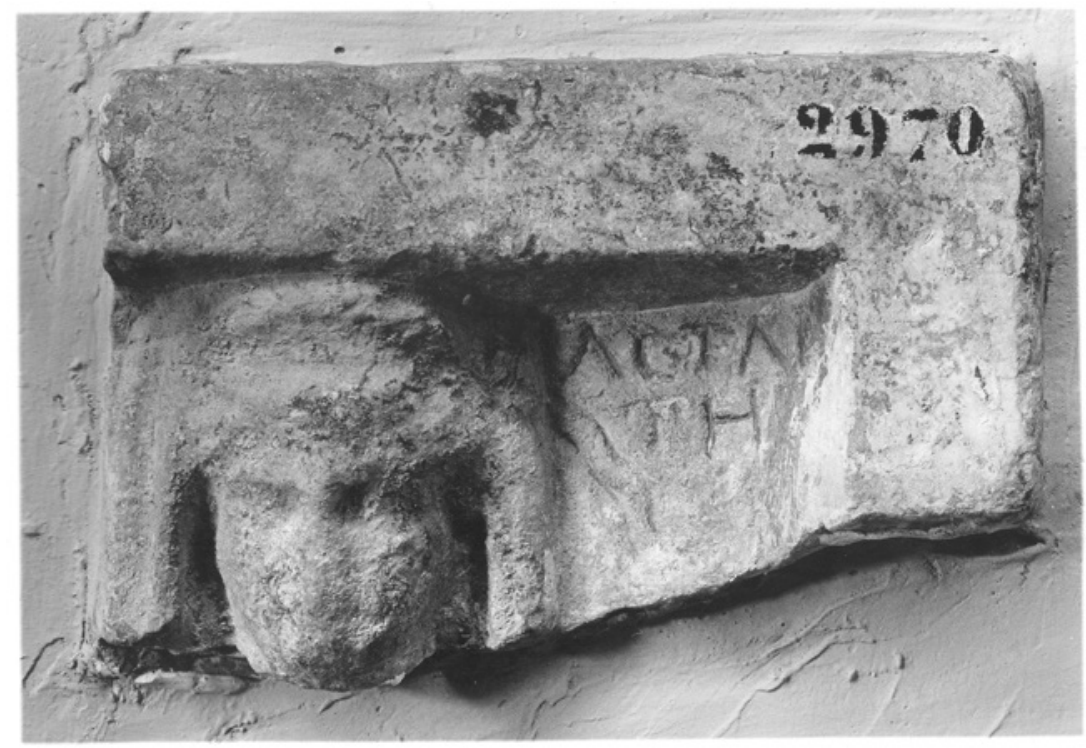

FIGURE 10.2 Fragment of marble relief with head of Astarte. $12 \times 18 \mathrm{~cm}$. Rome, Musei Capitolini 2970.

(PHOTO COURTESY OF THE MUSEI CAPITOLINI)

IGUR 120:

'A $\sigma \tau \alpha \dot{\rho}$

$\tau \eta$

Astarte's significant role alongside other divinities is well-attested at Palmyra, as discussed previously: she was venerated alongside Bel and her cult image apparently placed in an adyton added to the temple of Bel and Palmyrene gods during the second half of the first century AD. ${ }^{16}$ The relief has been linked erroneously to the goddess Dea Syria in Transtiberim in conjunction with the proposal that a sanctuary for Dea Syria existed in the neighborhood; however, it clearly belongs to the Palmyrene corpus, and no other dedications to Dea Syria (or to any other Syrian goddess) have secure archaeological provenances that attribute them to the area in question. ${ }^{17}$ The veneration of Astarte in Rome by

relief. Carlo Pietrangeli, Musei Capitolini. I monumenti dei culti orientali (Rome 1951), 14, cat. no. 15, subsequently discredited the idea due to the fragments' different depths.

16 Pietrzykowski 1997, op. cit. (n. 14); Kaizer 2002, op. cit. (n. 6), 198-200, and 2006, op. cit. (n. 12), 96 and 104-105. See also Dirven 1999, op. cit. (n. 9), 71.

17 See Blair Fowlkes, "The Cults of Syrian-Phoenician Gods in Rome: Archaeology, Topography, and Connections to the Roman East," Ph.D. diss. (New York University 2012), 
a Palmyrene therefore points toward a specific connection to Palmyra, rather than to integration in local religious life.

\section{$4 \quad$ Altar for Ares Patroios}

A marble altar dedicated to Ares Patroios embodies Palmyrene traditionalism with regard to (a) the choice of Greek for the inscription, (b) the use of the Seleucid calendar, and (c) the local incarnation of the god himself. Ares, in this instance, is considered to be the god Arşu, whose temple at Palmyra was one of four sanctuaries dedicated to the dei patri. ${ }^{18}$ The choice of Greek, as discussed above, reflects Palmyrene identity much less blatantly than does the Palmyrene language in the context of Rome. In contrast, the selection of an altar typical of dedications to all sorts of gods in Rome is significant as a reflection of the dedicator's integration at the capital.

IGRR I, 33; IGUR 122; IG XIV, 962:

April AD 134

' $\pi \dot{\rho} \rho \tau \eta ิ \varsigma \sigma \omega \tau \eta \rho \mid \alpha \varsigma$

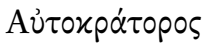

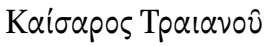

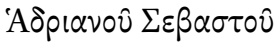

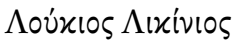

'Epuias

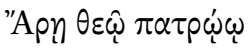

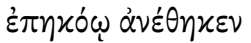

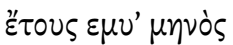

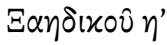

213-219, for full discussion. For proposals of a sanctuary for Dea Syria see in particular Serena Ensoli, "Communauté et cultes syriens à Rome: les sanctuaires de la regio XIV Transtiberim," in Jacques Charles-Gaffiot, Henri Lavagne, and Jean-Marc Hofman (eds.), Moi, Zénobie, reine de Palmyre (Milan 2001), 123-128; Serena Ensoli, "Il santuario della Dea Syria e i culti palmireni nell'area meridionale di Trastevere," Orizzonti 4 (2003), 45-59; Hans J.W. Drijvers, "Die Dea Syria und andere syrische Gottheiten im Imperium Romanum," in Maarten J. Vermaseren (ed.), Die orientalischen Religionen im Römerreich (Leiden 1981), 241-263.

18 Equini Schneider 1987 , op. cit. (n. 5), 72 and note 20. 
The dedicator Lucius Licinius Hermias shares the same gentilicium as the benefactor named in $C I L \mathrm{VI}, 50$ and 51 discussed previously; so again, there is perhaps a connection here to the Licinii back in Palmyra.

\section{5}

An aedicula (and a Silver Statuette) for Aglibol and Malakbel

The Palmyrene dedication with the latest date extant in Rome is a lavish marble aedicula dated to February 236 : the conventionalism of the depictions of Aglibol and Malakbel, and of the dedicatory inscriptions, is noteworthy (Fig. 10.3). Dressed in a cuirass and cloak, Aglibol, on the right, holds a lance in his left hand and a radiate nimbus and lunar crescent are visible behind his head. Malakbel wears a diadem and the characteristic Palmyrene outfit of trousers, a short tunic and an open overcoat. The gods shake hands in front of a cypress tree between them: the handshake as a gesture of "alliance" has been interpreted as a sign that the two gods represent the "Sacred Brothers" mentioned in various Palmyrene texts, venerated together in a sacred grove and depicted on a relief from the temple of Bel and Palmyrene gods at Palmyra. ${ }^{19}$

The adherence to customary Palmyrene iconography is matched by the choices of Greek and Palmyrene and the emphasis placed on the dedicator's ancestry: Adams suggests also that Latin may not have been appropriate for this type of religious dedication. ${ }^{20}$ Iarhai (translated into Greek as Heliodoros, according to Palmyrene convention) dedicated the aedicula, and a silver statuette, to Aglibol and Malakbel for his own and his son's well-being.

IGUR 119; IG XIV, 971; IGRR I, 45:

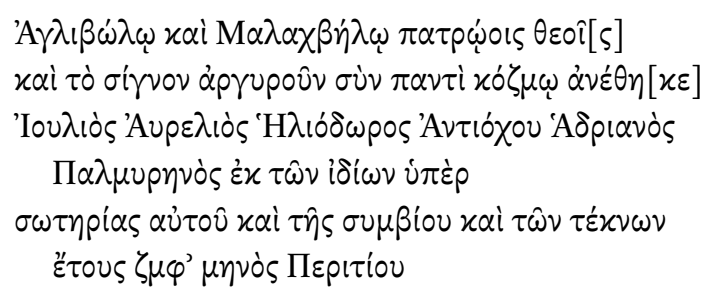

\footnotetext{
19 See Equini Schneider 1987, op. cit. (n. 5), 82 and note 71 for additional references. See also Dirven 1999, op. cit. (n. 9), 175 and Fig. 17.

$20 \quad$ Adams 2003, op. cit. (n. 4), $25^{2}$.
} 


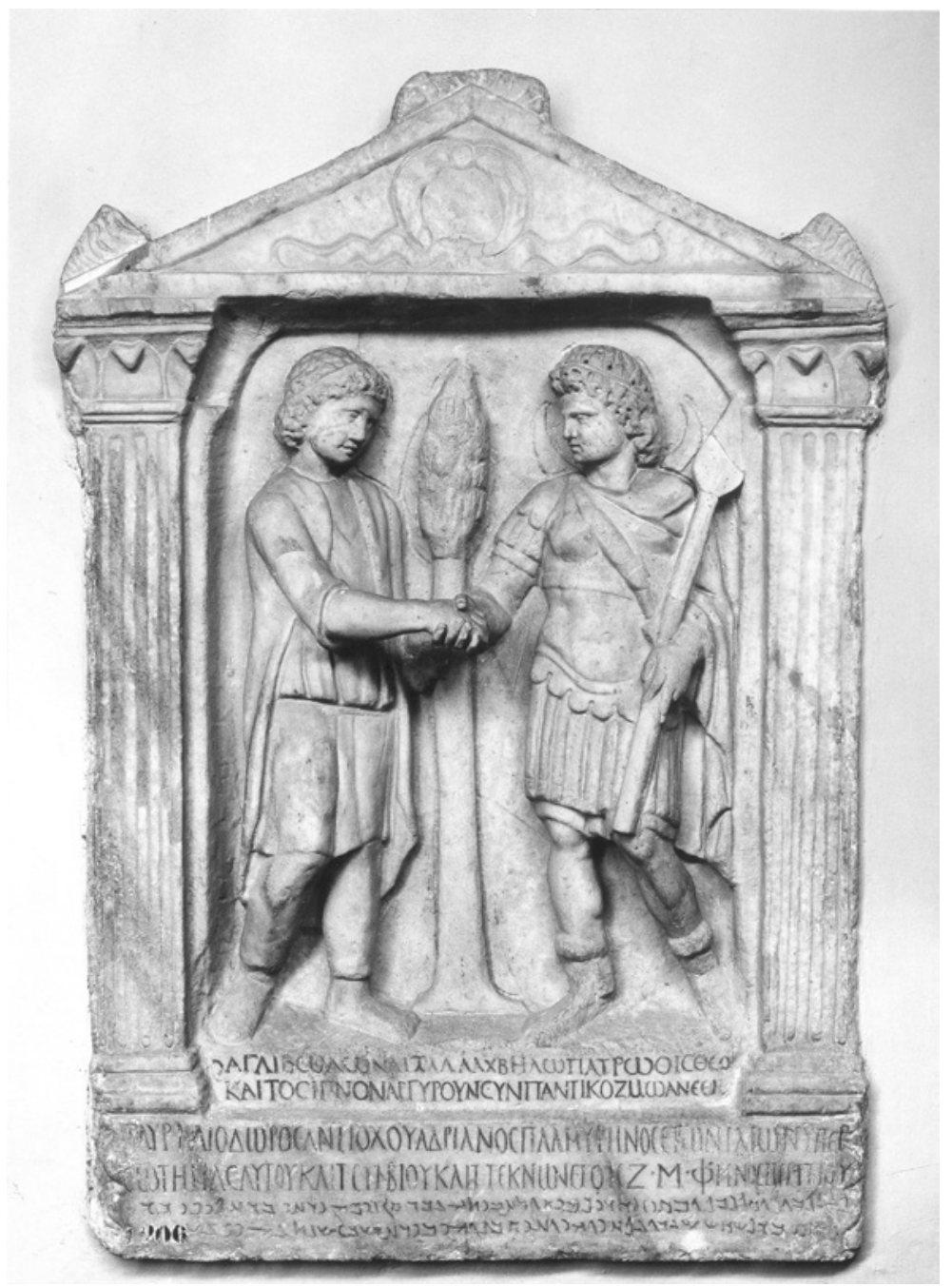

FIGURE 10.3 Marble aedicula for Aglibol and Malakbel. February 236. $97 \times 63 \mathrm{~cm}$. Rome, Musei Capitolini 1206.

(PHoto COURTESY OF THE MUSEI CAPITOLINi)

CIS II, 3, no. 3902; PAT 0247:

English translation of the Palmyrene Aramaic (Adams 2003, 251-252)

To Aglibol and Malakbel: both the silver statue and its decoration Iarhai son of Haliphai, son of Iarhai, son of Lisams (son of) Šo'adu made from his purse for his own safety and that of his sons; in the month Shebat of the year 547 . 
As a group, the two dedicatory inscriptions, the two relief sculptures, the altar for Ares Patroios and the aedicula for Aglibol and Malakbel illustrate how members of the Palmyrene community in Rome explicitly expressed connections to their native city's civic religion and customs. Traditionalism prevails in general with regard to choices of language and iconography, with a couple of exceptions as noted, including the use of Latin for dedicatory inscriptions and the choice of an altar for Ares Patroios rather than a relief sculpture.

A lavish marble altar dedicated to Sol, Malakbel and additional unspecified Palmyrene gods is the most renowned object in the corpus of Palmyrene religious dedications from Rome, standing out vividly with respect to its iconography, the use of Latin for one of the two dedicatory inscriptions, and the information available about the dedicators' identities (Figs. 10.4a-10.4d). A production date in the early second century is likely. ${ }^{21} \mathrm{~A}$ reevaluation of this monument is essential in order not only to integrate the study of its imagery and inscriptions, but also to consider local religious topography and its possible original display context fully. I propose that the dedicators commissioned a monument that distinguishes purposefully between the gods Sol and Malakbel, and most likely commemorates two distinctive dedications, as recorded in Latin and Palmyrene inscriptions that are not translations of one another. Analysis of the identities of the two gods and of the dedicators raises key questions about Palmyrenes' degree of assimilation in Rome and about connections between different cult sites. The exact location of the Palmyrene temple is indeterminable; however, a porticus for Sol (and probably a sanctuary as well) was apparently located nearby, and supports the idea that the Sol/ Malakbel altar honors both gods individually. Ultimately, by focusing on the glimpse of religious interaction in Rome the altar provides, in contrast to the rest of the corpus, this new interpretation of a complex monument heightens our understanding of the integration of foreigners and links between the capital and the empire's frontiers. ${ }^{22}$

21 See the discussion by George W. Houston, "The Altar from Rome with Inscriptions to Sol and Malakbel," Syria 67 (1990), 191-192, who revises the third-century date proposed most recently by Javier Teixidor, The Pantheon of Palmyra. Études preliminaires des religions orientales 79 (Leiden 1979), 50.

22 For a bibliography and substantial discussion of previous theories, see Dirven 1999, op. cit. (n. 9), 175-180 and accompanying notes. See in particular also Equini Schneider 1987, op. cit. (n. 5), 73-78; Henry Stuart Jones (ed.), A Catalogue of the Ancient Sculptures 

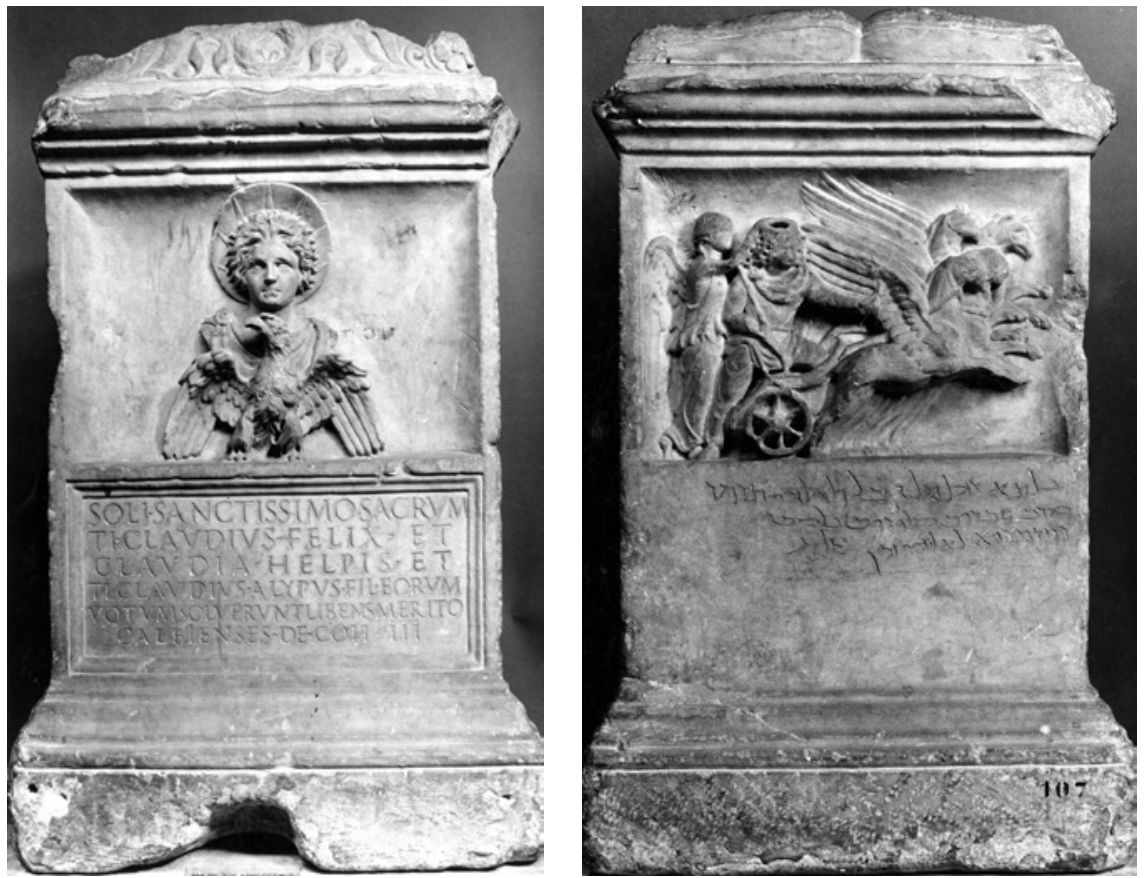

$10.4 \mathrm{~A}$

$10.4 \mathrm{~B}$
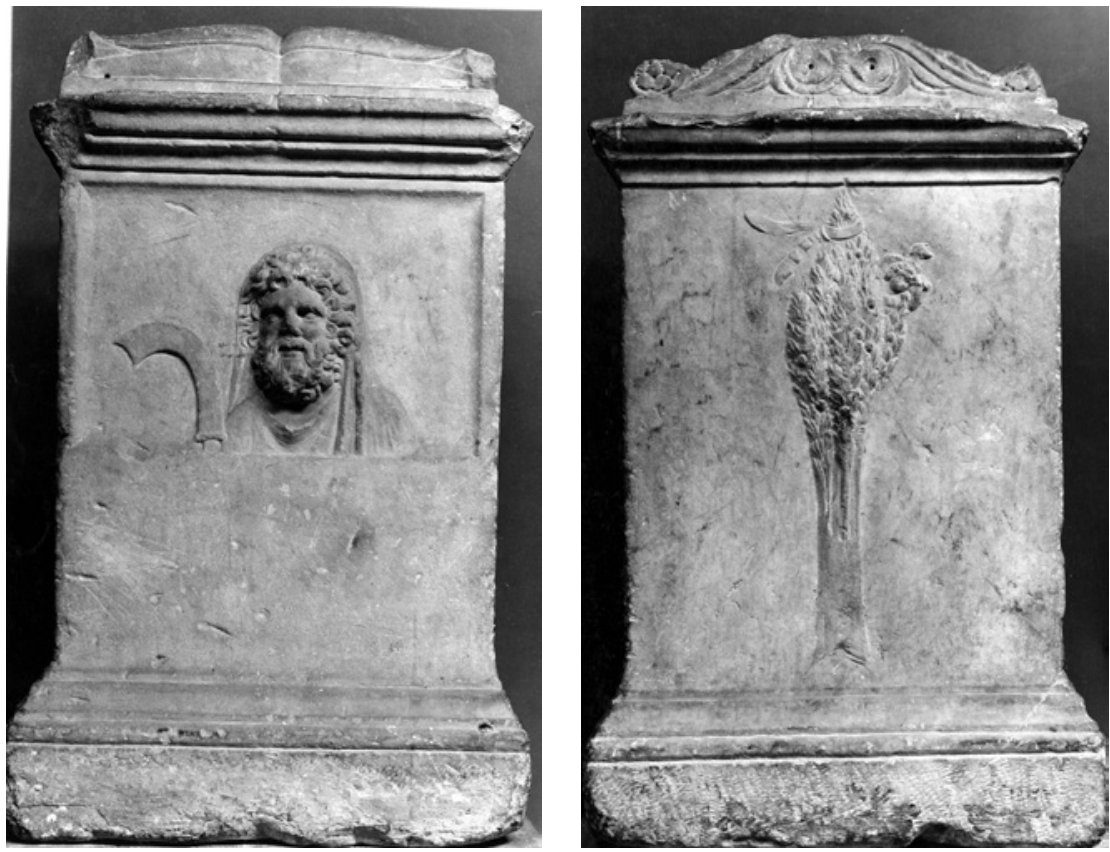

$10.4 \mathrm{C}$

10.4D

FIGURE $10.4 \quad 4 a$ and $b$. Sol/Malakbel Altar. $84 \times 52 \times 52 \mathrm{~cm}$. Rome, Musei Capitolini, NCE 2412. Fig. $4 \mathrm{c}$ and . Sol/Malakbel Altar.

(PHOTO COURTESY OF THE MUSEI CAPITOLINI) 
The altar's most prominent side, due to the orientation of the pulvini, features a bust of Sol carved in high relief placed on an eagle above a straightforward Latin inscription, which records a dedication to Sol Sanctissimus by Tiberius Claudius Felix, his wife Claudia Helpis and their son Tiberius Claudius Alypus (Fig. 10.4a). The choice of Latin is of course entirely appropriate for a dedication to Sol in the context of Rome, but stands out as noteworthy in comparison with the other language choices made throughout the corpus of Palmyrene dedications in Rome discussed previously.

$C I L$ VI, $710=30817 ; I L S$ 4337:

Soli sanctissimo sacrum

Ti(berius) Claudius Felix et

Claudia Helpis et

Ti(berius) Claudius Alypus fil(ius) eorum

votum solverunt libens merito

Calbienses de coh(orte) III

George Houston solved the puzzle of the meaning of the term Calbienses by identifying the three dedicators as residents of the third courtyard of the Horrea Galbana in the Emporium zone on the right bank of the Tiber. ${ }^{23}$

Turning to the image of Sol, the idea that the figure represents Malakbel in his role as a solar deity ${ }^{24}$ is unconvincing in view of the use of the standard iconography of Sol and the fact that the dedicators were apparently civilians. Above all, one must consider the significance of such a representation for a contemporary viewer in the city of Rome (the dedicators included), whether or not this audience was able to read the Latin inscription. No hint of any Palmyrene connections is evident: the figure's appearance and pose

Preserved in the Municipal Collections of Rome: the Sculptures of the Palazzo dei Conservatori (Oxford 1926), 47, no. 1 and Pietrangeli 1951, op. cit. (n. 16), 21, no. 33. Werner Herrmann, Römische Götterältare (Kallmunz 1961), 113, provides a detailed description of the altar's type and design.

23 Houston 1990, op. cit. (n. 21), 191: the term Calbienses was interpreted previously as a Palmyrene tribal affiliation. He cites Rodríguez Almeida's study of the horrea Galbae and explains that the building with three courtyards is in fact living quarters, not a warehouse (Emilio Rodríguez Almeida, "Cohortes III Horreorum Galbanorum." Rendiconti della Pontificia Accademia di Archeologia di Roma 50 (1977-78), 9-25).

24 Equini Schneider 1987, op. cit. (n. 5), 81; Dirven 1999, op. cit. (n. 9), 178. The term sanctissimus is apparently a rare epithet for the god Sol, however, and therefore Steven Hijmans, "Sol. The Sun in the Art and Religions of Rome," (Ph.D. diss. Universiteit Groningen 2009), 506 , note 90 , characterizes Sol in this instance as equated with Malakbel. 
reflect conventional Roman iconography for the god Sol. He is youthful, beardless and radiate, depicted in bust form above an eagle: the similar image of Sol on a cippus dedicated by a wine merchant provides an apt comparison (Fig. 10.5). A frumentarius' dedication to Sol Invictus Malachbelus discovered in Rome indicates that Malakbel could be linked to Sol Invictus in the capital; ${ }^{25}$ however, the fact that the dedicator was a member of the military is notable. Dirven strongly emphasizes the differences between merchants' and soldiers' religious choices in her study of Palmyrene gods at Dura-Europos, and comments specifically on Malakbel's role as a solar deity among the military. ${ }^{26} \mathrm{In}$ brief, there is no reason to conclude from the iconography, from the Latin inscription, or from the dedicator that the radiate figure on the Sol/Malakbel altar represents any deity other than the Roman god Sol.

On the altar's left side, a representation of Malakbel appears above a Palmyrene inscription that records a dedication to Malakbel and the gods of Palmyra by Tiberius Claudius Felix and the Palmyrenes (Fig. 10.4b). ${ }^{27}$ Victory crowns Malakbel as he climbs into a chariot pulled by four winged griffins: he wears trousers and a mantle and holds a spear in his right hand. The scene is comparable to one on an altar from the sanctuary of Baalshamin at Palmyra:28 both representations very likely copy a cult image of Malakbel at Palmyra, and the dedicators of the Rome altar therefore emphasize their connection to their home city through a deliberate iconographic choice.

Information from the Palmyrene inscription about the dedicators and their relationships with one another underscores the complexity inherent in an attempt to identify foreigners and assess their level of integration in Rome. Three English translations of the Palmyrene inscription merit inclusion due to their slightly different characterizations of the dedicators' roles. A deliberate distinction between two groups of dedicators is apparent, regardless of Claudius Felix's involvement in both, since the Latin inscription refers to an

$25 C I L$ VI, $31036=$ ILS 4338. [D]eo Soli Inv[icto] / Malachibe[lo] / Aelius Long[---] / (centurio) frument(arius) / pr [o salute --- ]/[---]liae / [---]niv[--]. Museo Nazionale Romano. See also Equini Schneider 1987, op. cit. (n. 5), 80; Chausson 1995, op. cit. (n. 2), 679, Pbis; Hijmans 2009, op. cit. (n. 24), 495-496, l.

26 Dirven 2011, op. cit. (n. 3), 201-220; Dirven 1999, op. cit. (n. 9), 170 and 181-183.

27 Teixidor 1979, op. cit. (n. 21), 47.

28 Palmyra Museum. Dirven 1999, op. cit. (n. 9), 161-162 and pl. xxıII: she also mentions another possible representation of Malakbel from the temple of the Gaddé at DuraEuropos and two tesserae from Palmyra representing a deity in a quadriga pulled by griffins. See also Equini Schneider 1987, op. cit. (n. 5), 78 and Fig. 10. 


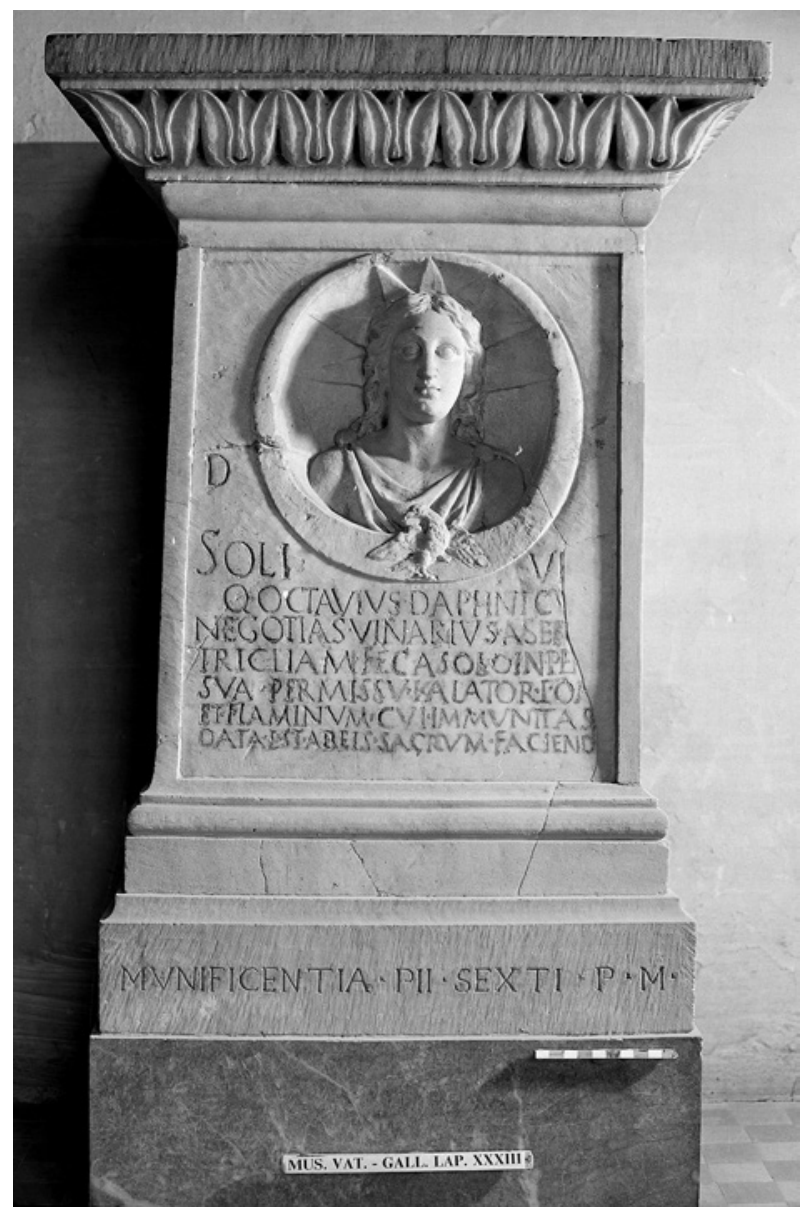

FIGURE 10.5 Cippus for Sol. Musei Vaticani.

(PHOTO COURTESY OF THE MUSEI VATICANI)

earlier vow made by Tiberius Claudius Felix, his wife and their son, as Houston emphasizes. $^{29}$

CIS II, no. 3903; PAT 0248.

CIS II, no. 3903:

Tiberius Claudius Felix has offered this altar to

Malakbel and the gods of Palmyra. And the

Palmyrenes (have offered it) to their gods. Peace.

29 Houston 1990, op. cit. (n. 22), 192-193. 


\section{Teixidor 1979, 47:}

This is the altar (which) Tiberius

Claudius Felix and the Palmyrenes

offered to Malakbel and the gods of

Palmyra. To their gods. Peace!

\section{Dirven 1999, 177:}

This altar (is) for Malakbel and the gods of

Palmyra. Tiberius Claudius Felix and the Palmyrenes offered it to their gods.

Peace.

Debate centers on Tiberius Claudius Felix's origins, occupation, and connection to the "Palmyrenes" mentioned. Adams characterizes him as a Palmyrene too, whose acculturation leads him to adopt a Latin name completely, and mentions "his assimilation and desire to present a Roman identity alongside the Palmyrene." ${ }^{30}$ The wording of the inscription, however, separates him clearly from "the Palmyrenes" about whom no additional information is provided. The possibility that they were slaves of the imperial household ${ }^{31}$ may explain Claudius Felix's role as a facilitator of the dedication if he were an imperial freedman, but does not indicate that he was necessarily a Palmyrene himself. In any case, whatever his ancestral origins actually were, his specific desire to identify himself with a Latin name separately from the "Palmyrenes" is clear.

The marble altar itself, in addition to the actual figures carved in relief, was most probably a commissioned work in view of its size and high quality: all four sides may have been clearly visible in the altar's original setting, since the carving on the two uninscribed sides is detailed..$^{32}$ The Sol side is visually the most prominent due to the orientation of the pulvini, as mentioned: the fact that two sides are inscribed, however, indicates that both may have been of equal

$30 \quad$ Adams 2003, op. cit. (n. 4), 250-53. Equini Schneider 1987, op. cit. (n. 5), 77 and notes 41 and 42 , suggests that he is a libertus connected to the horrea, rather than a vilicus, who would most likely be a slave, and also argues in favor of his Palmyrene origin. David Noy, Foreigners at Rome: Citizens and Strangers (London 2000), and Dirven 1999, op. cit. (n. 9), 179-80, do not believe that Tiberius Claudius Felix is definitely a Syrian.

$31 \quad$ Equini Schneider 1987, op. cit. (n. 5), 77.

32 For a discussion of sculptors' workshops in Rome, see Amanda Claridge, "Marble Carving Techniques, Workshops, and Artisans," in Elise A. Friedland and Melanie Grunow Sobocinski (eds.), The Oxford Handbook of Roman Sculpture (Oxford and New York, 2015), $113^{-114}$ 
importance to the dedicators irrespective of the pulvini. The figures depicted on the altar's two other sides are not easily identifiable. The most straightforward explanation is that they represent the unnamed Palmyrene gods mentioned in the Palmyrene inscription. Alternatively, the bearded male figure with a mantle pulled over the back of his head and a scythe on the altar's right side could represent Saturn (Fig. 10.4c). ${ }^{33} \mathrm{~A}$ tall cypress tree on the altar's rear side has a ribbon in its top branches and the figure of a boy with a goat on his shoulders emerges from the top right of the tree (Fig. 10.4d). The tree is a possible reference to a cult site for Malakbel in a sacred grove and the young boy could represent him in his role as an agrarian deity.

An understanding of local religious topography derived from epigraphic and archaeological evidence corroborates the idea that the Sol/Malakbel altar commemorates two distinctive dedications, raises the question of its original display context, and draws attention to the "cultic realities on the ground,"34 to borrow Kaizer's words, that provide a glimpse of Palmyrenes' integration within Rome. Almost all of the dedications to Palmyrene gods were discovered in 1859 during Carlo Ludovico Visconti's excavations at the Vigna Bonelli in Trastevere outside the Porta Portese: precise information about the location of the archaeological site or about architectural structures is unavailable. ${ }^{35}$ The Vigna Bonelli's boundaries are marked on Giambattista Nolli's 1748 Pianta di Roma labeled with the property's previous name, Vigna Crescenzi (Fig. 10.6). Additional inscriptions also discovered at the Vigna Bonelli indicate that a porticus of Sol separate from the Palmyrene temple existed: it was administered by the priesthood of kalatores and therefore connected to a public Roman cult of the god. In his comprehensive study of Sol, Steven Hijmans cites the "unfounded communis opinio of earlier scholarship that the cult of Sol in the imperial era was of Syrian origin" as the reason for persistent confusion between the cult sites for Palmyrene gods and for Sol. ${ }^{36} \mathrm{He}$ also draws

33 See also Dirven 1999, op. cit. (n. 9), 178 and note 75 .

$34 \quad$ Kaizer 2002, op. cit. (n. 6), 58.

35 The aedicula and the Sol/Malakbel altar do not have secure archaeological provenances and both were part of the Mattei family's antiquities collection. Christian Hülsen, Römische Antikengärten des XVI. Jahrhunderts (Heidelberg 1917), 62, no. 53, gives no information about the aedicula's archaeological provenance. Pirro Ligorio and the CIL editors report that the Sol/Malakbel altar was found in the vigna of Mario Scapuccio on the Janiculum hill: see Fowlkes 2012, op. cit. (n. 17) 191-193 for references. CIL VI, 51 (now in the British Museum) is the only other object not discovered during the excavations. See Visconti 1860, op. cit. (n. 15), 415-450.

36 Hijmans 2009, op. cit. (n. 24), 486 and 501. See also Steven Hijmans, "The Sun which did not rise in the East; the Cult of Sol Invictus in the Light of Non-Literary Evidence," Bulletin 
attention to an aedicula for Silvanus also discovered during the 1859 Vigna Bonelli excavations as an additional important piece of evidence that various sanctuaries/cult sites were located in the same general area, despite the dearth of information about their precise locations. ${ }^{37}$

$C I L \mathrm{VI}, 31033^{1}$ and $C I L$ VI, $5^{2}$ both refer respectively to a porticus of Sol and triclias, likely a variant spelling of trichila, defined as a "gazebo" or "bower". 38 CIL VI, 310331 records that the benefactor, Iulius Anicetus, restored the porticus with the kalatores' permission in AD $102 .{ }^{39}$ The mention of a porticus, but not an aedes, is apparently a rare occurrence, and perhaps an indicator that the sanctuary was open-air, typical for Sol. ${ }^{40} \mathrm{CIL}$ VI, $5^{2}$ records Anicetus' request that the walls and triclias of the sanctuary not be written on or defaced. ${ }^{41}$ Hijmans' comments on the two inscriptions are worth quoting in full, as he draws a crucial distinction between the gods Bel and Sol and their respective cult sites:

Antieke Beschaving 71 (1996), 115-150. Visconti 186o, op. cit. (n. 15), 424; Luigi Borsari, "Del gruppo di edificii sacri al Sole nell'area degli orti di Cesare," Bullettino della Commissione Archeologica di Roma 15 (1887), 9o; Palmer 1981, op. cit. (n. 33), 372-373, and Chausson 1995, op. cit. (n. 2), 663-664. Equini Schneider concurs that the Sol inscriptions are not relevant to the cult of Bel (s.v. "Belus/Malachbelus," LTURS I (2001) 218 (E. Equini Schneider). Robert E.A. Palmer, “The Topography and Social History of Rome's Trastevere (Southern Sector)," Proceedings of the American Philosophical Society 125.5 (1981), 372-373, proposes a "sanctuary of the Sun" on the Via Longa Aquilae; Chausson 1995, op. cit. (n. 2), 663-664 follows this interpretation. Serena Ensoli attributes epigraphic evidence from multiple cult sites to one major sanctuary in Reg. XIV, which she refers to as the "santuario siriano" (“Deae Syriae Templum (280)," LTURS II (2002), 192 (S. Ensoli) and Ensoli 2003, op. cit. (n. 17), $5^{2}$.

37 CIL VI, 642; Hijmans 2009, op. cit., (n. 24), 489, h; Visconti 1860, op. cit. (n. 15), 448-450.

38 Palmer 1981, op. cit. (n. 35), 375, suggests that open-air rooms may have been connected to, or part of, the porticus. Chausson 1995, op. cit. (n. 2), 667, suggests that the term is an abbreviation for triclinium. See also Hijmans 2009, op. cit. (n. 24), 503.

$39 \quad C I L$ VI, $3719=310331$. The inscription was discovered during two different nineteenthcentury excavations: Visconti 1860 , op. cit. (n. 15), reports that the bottom half was unearthed during Giambattista Guidi's 1859 excavation, and Rodolfo Lanciani found the top half in 1884 (Carlo Ludovico Visconti and Rodolfo Lanciani, "Il busto di Anacreonte scoperto negli orti di Cesare," Bullettino della Commissione archeologia di Roma 12 (1884), 25-38). Hijmans 2009, op. cit. (n. 24), 486 and note 23; 492, k; C2b.2: he also notes (151) that a Neronian foundation date is plausible in comparison with other Sol sanctuaries throughout the city.

$40 \quad$ Hijmans 2009, op. cit. (n. 24), 503 and note 72.

41 The wine merchant's altar for Sol, discussed previously, mentions a triclia as well, and is also, therefore, attributable to the same Sol sanctuary (it was discovered in the Tiber near the Ponte Rotto) (Fig. 5). 


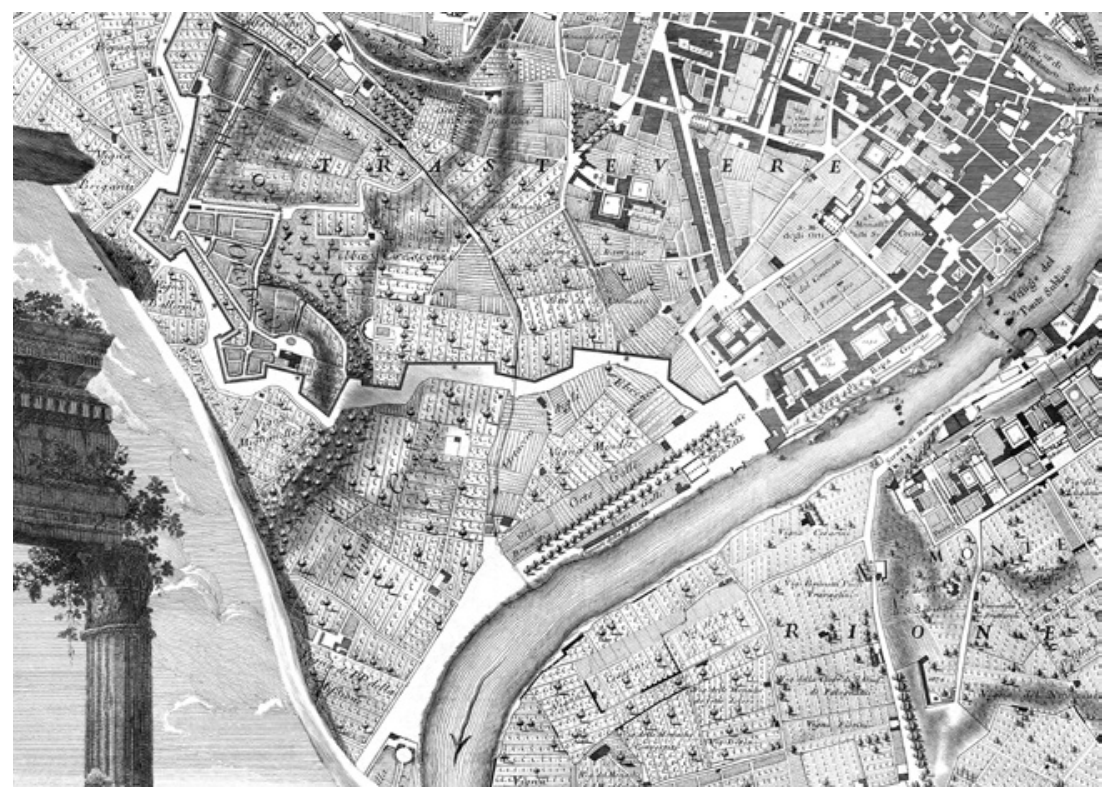

FIGURE 10.6 Detail of Giambattista Nolli's 1748 Pianta di Roma. The Vigna Crescenzi (later named the Vigna Bonelli) is circled.

(COURTESY OF THE NOLLI MAP PROJECT, UNIVERSITY OF OREGON, HTTP://NOLLI.UOREGON.EDU)

There is no evidence that Anicetus' porticus was connected to the temple of Bel, and strong reasons to think that it was not. To begin with, Bel is not Sol, and the inscription cannot, therefore, refer to a porticus "of the temple of Bel". In the second place, the inscriptions of Anicetus give no evidence of any Palmyrene connections: their language is Latin only, the deity is given a Latin name with no indication that a non-Roman deity is meant, permission of the kalatores pontificum et flaminum is involved, implying Roman rather than foreign cult, and the consular rather than the Seleucid dating system is used. The only reasonable conclusion is that Anicetus' inscriptions belong to a portico (and sanctuary?) of Sol that stood in the same general area but was unrelated to a Palmyrene sanctuary of Bel. ${ }^{42}$

Despite the limited archaeological evidence from the Vigna Bonelli site, Hijmans' convincing reinterpretation of the epigraphic evidence for the porticus and the Palmyrene temple dispels previous confusion about local religious topography. 
Choices of language, iconography and medium throughout their corpus of dedications illustrate how purposefully and openly numerous Palmyrenes in Rome emphasized their links to Palmyra, providing insight into a community of foreigners within the capital. The specific mention of different dedicators in distinctive inscriptions, the iconography and religious topography all support the idea that the Sol/Malakbel altar commemorates separate dedications to the Roman god Sol and to Malakbel and Palmyrene deities, linked together by Tiberius Claudius Felix's involvement in both. The question arises whether such a monument was originally dedicated and displayed at the Sol porticus or at the Palmyrene temple, or perhaps at another location. In any case, the altar indicates that Palmyrenes (or at least a particular group of them) most likely had a connection/level of access to the Sol porticus in addition to their own temple, an important sign of integration in Rome that prompts a comparable interdisciplinary approach to other religious dedications made by newcomers to the city from the Empire's edges and frontiers. 